Animal Production and Environment Received on: 11/11/2019 Accepted on: 07/07/2020

\title{
Production and composition of milk per Holstein and Jersey cow from two farms in northwest Rio Grande do Sul
}

\author{
Produção e composição do leite de vacas Holandês e Jersey de duas propriedades \\ rurais no Noroeste do Rio Grande do Sul
}

\author{
CALGARO, Júlia Laize Bandeira ${ }^{1}$ \\ https://orcid.org/0000-0002-2064-7376 \\ FIORESI, Júnior ${ }^{2}$ \\ https://orcid.org/0000-0002-2222-8087 \\ VELHO, João Pedro ${ }^{3}$ \\ https://orcid.org/0000-0003-3901-8200 \\ STROEHER, Fernanda Hammes ${ }^{1}$ \\ https://orcid.org/0000-0002-4188-5971
}

ALESSIO, Dileta Regina Moro 4

https://orcid.org/0000-0001-5549-9388

\author{
PIUCO, Marcos André \\ https://orcid.org/0000-0002-8398-2075 \\ WEBER, Carol Thaís ${ }^{2}$ \\ https://orcid.org/0000-0003-3319-9944
}

HAYGERT-VELHO, Ione Maria Pereira ${ }^{3 *}$

https://orcid.org/0000-0002-6709-7340

\begin{abstract}
${ }^{1}$ Universidade Federal de Santa Maria, Campus de Palmeira das Missões, Programa de PósGraduação em Agronegócios, Palmeira das Missões, Rio Grande do Sul, Brazil.

${ }^{2}$ Universidade Federal de Santa Maria, Campus de Palmeira das Missões, Curso de Graduação em Zootecnia, Palmeira das Missões, Rio Grande do Sul, Brazil.

${ }^{3}$ Universidade Federal de Santa Maria, Campus de Palmeira das Missões, Departamento de Zootecnia e Ciências Biológicas, Palmeira das Missões, Rio Grande do Sul, Brazil.

${ }^{4}$ Centro Universitário Leonardo da Vinci, UNIASSELVI, Núcleo de Educação a Distância, Indaial, Santa Catarina, Brazil.

${ }^{5}$ Escola Estadual Técnica Celeste Gobbato, Palmeira das Missões, Rio Grande do Sul, Brazil.

* Mailing address: ione.h.velho@ufsm.br
\end{abstract}

\begin{abstract}
The aim of the present study was to monitor cow milk quality and composition in two farms in the Noroeste Rio-grandense mesoregion, located in the municipalities of Palmeira das Missões and Pinhal - RS. Both herds were mixed, with animals of the Holstein $(70 \%)$ and Jersey $(30 \%)$ breeds. The following overall parameters were evaluated: body condition score (BCS), udder dirtiness, and calving order, and the following milk composition factors were measured: total dry extract (TDE), defatted dry extract (DDE), milk lactose, fat, and protein contents, casein, milk urea nitrogen (MUN), and somatic cell count (SCC). Multivariate statistical analysis was performed, and four factors were identified representing combinations of the measured variables. The first factor comprised negative relationships between milk production and cow breed, milk fat content, and milk protein content. The second factor comprised the positive relationships between lactation days and body condition score and milk protein content. The third factor represented the negative relationships between milk lactose content and SCC score, calving order, and BCS. The fourth factor was composed of the positive relationship between delivery order and udder dirtiness. Cluster analysis revealed that individual cows
\end{abstract}


could be categorized into three groups. Monitoring the breed, calving order, body condition score, lactation days, milk production, fat, protein, and lactose contents, somatic cell counts, and udder dirtiness in cows allows greater control of the herd, allowing potential shortcomings to be rectified quickly and economic losses to production to be minimized.

Keywords: Body condition score, fat, lactose, protein, somatic cell count

\section{RESUMO}

Objetivou-se realizar o monitoramento por vaca em lactação referente a qualidade e composição do leite de duas propriedades rurais na mesorregião Noroeste Rio-grandense, localizadas nos municípios de Palmeira das Missões e Pinhal - RS. Ambos os rebanhos eram mistos, com animais da raça Holandês (70\%) e Jersey (30\%). Foram avaliados os parâmetros: escore de condição corporal (ECC), sujidade de úbere, ordem de parto e composição do leite: teores de extrato seco total (EST) e desengordurado (ESD), lactose, gordura, proteína, caseína, nitrogênio ureico do leite (NUL) e contagem de células somáticas (CCS). A análise estatística realizada foi análise fatorial e de agrupamento. $\mathrm{O}$ primeiro fator compreende a relação negativa da produção de leite com a raça, teor de gordura e proteína. O segundo fator compreende a relação positiva entre dias em lactação com escore de condição corporal e teor de proteína do leite. O terceiro fator é representado pela relação contrária do teor de lactose com escore de CCS, ordem de parto e ECC. No quarto fator observa-se a relação positiva entre ordem de parto e sujidade do úbere. $\mathrm{Na}$ análise de agrupamento foram formados três grupos que refletem as relações encontradas na análise fatorial. O monitoramento por vaca, considerando raça, ordem de parto, escore de condição corporal, dias em lactação, produção de leite, teores de gordura, proteína e lactose, escore de contagem de células somáticas e sujidade do úbere possibilitam maior controle do rebanho, facilitando corrigir possíveis deficiências pontuais de forma rápida e minimizando as perdas produtivas e econômicas.

Palavras-chave: contagem de células somáticas, escore de condição corporal, gordura, lactose, proteína

\section{INTRODUCTION}

In the last 100 years, dairy cattle farming has evolved considerably in relation to fluid milk production (Barbano, 2017), rearing systems (Bewley et al., 2017), and temperate pasture management (Roche et al., 2017). In addition, animal welfare (Von Keyserlingk \& Weary, 2017) has been greatly enhanced, with the improved diagnosis, treatment, and prevention of mastitis (Ruegg, 2017). Despite this evolution in dairy cattle farming, not all novel technologies are available or are viable for rural producers in countries like Brazil.
The need to evaluate milk composition is partly due to the fact that metabolism during pregnancy and lactation involves two types of regulation in cows: homeostasis and homeorhesis. Homeostatic control maintains the physiological balance or the constancy of environmental conditions within the animal, and homeorhesis refers to the orchestrated or coordinated control of metabolism in body tissues necessary to support a physiological state (Bauman \& Currie, 1980; Baumgard et al., 2017). Therefore, the combination of homeostasis and homeorhesis impacts voluntary food intake, the biochemical 
profile of the animal, production, and milk composition, and part of this metabolism can be monitored through evaluating milk and blood constituents (Campos et al., 2008; Wheelock et al., 2010). However, evaluating the milk is more pertinent because it is not invasive and can be carried out on any rural property during milking, as currently the convention in specialized herds has been to milk cows twice daily.

In a study carried out using a database from the Associação Paranaense de Criadores de Bovinos da Raça Holandesa, (719 herds, 87,685 Holstein cows, and 1,688,054 official assessments), between January 2010 and December 2015, Gonçalves et al. (2018) concluded that losses due to the somatic cell count occur in the following stages, in ascending order: first lactation ( 0.55 to $0.97 \mathrm{~kg} / \mathrm{d}$ ), second lactation (1.09 to 2.45 $\mathrm{kg} / \mathrm{d}$ ) and third lactation (1.13 to 2.65 $\mathrm{kg} / \mathrm{d}$ ), demonstrating that it is essential to reduce the somatic cell count to increase productivity.

The aim of milk quality payment programs is to improve milk quality through a monetary incentive that is paid to the producer per liter of milk (Busanello et al., 2017a). Thus, the objective of the present study was to monitor the quality and composition of milk of lactating cows from two rural properties in northwestern Rio Grande do Sul.

\section{MATERIALS AND METHODS}

The description of the methodology will be divided into two parts, each referring to the database (DB) of one rural property, and the common procedures will be addressed together. The two DB refer to information from their respective herds collected between August and October 2018, with milk collections every 15 days, as described below, totaling five assessments from the rural property in Palmeira das Missões - RS, and four assessments from the rural property in Pinhal - RS.

The first DB was obtained from the Educational Production Unit (UEP) Bovinocultura de Leite of the Escola Estadual Técnica Celeste Gobbato (EETCG), located in the municipality of Palmeira das Missões, RS, Brazil ( $-27^{\circ}$ 95' 19', $-53^{\circ} 29^{\prime}$ 95'). The 27 hectare area was used to rear lactating cows, dry cows, heifers, and calves. The management system used by the UEP Bovinocultura de Leite - EETCG is detailed in Haygert-Velho et al. (2018). In brief, the dairy herd consisted of $30 \%$ Jersey cows and 70\% Holstein cows. The animals were supplied with oat pasture (Avena strigosa) and/or ryegrass (Lolium multiflorum) and BRS Tarumã wheat (Triticum aestivum). Corn silage (Zea mays) was given in a trough, and concentrate was offered according to individual milk production.

The other property is located in the municipality of Pinhal, RS, Brazil (-27 30 ' $\left.21^{\prime \prime},-53^{\circ} 13^{\prime} 35^{\prime \prime}\right)$, and covers an area of 27.7 hectares used for rearing lactating cows, dry cows, and heifers. The property has a milking parlor and a shed for feeding.

The dairy herd consisted of $30 \%$ Jersey cows and 70\% Holstein cows. Animals were supplied with corn silage (Zea mays), chopped tifton hay (Cynodon sp.), and cotton seed (Gossypium hirsutum) with linter. The amount of concentrate offered was related to individual milk production. The pasture offered was composed of white oats (Avena sativa) and ryegrass (Lolium multiflorum), with some areas of white clover (Trifolium repens) and BRS Tarumã wheat (Triticum aestivum). 
In both properties, milking was carried out twice a day, with collection every 15 days. For all milkings, the first jets were taken after pre-dipping, drying the ceilings with disposable paper towels, and California Mastitis Tests (CMT) were administered. The results of the CMT are expressed as scores (a score of 0 represents absent viscosity, dashes are mild, + indicates mild to moderate, ++ indicates moderate, and +++ indicates intense viscosity) to monitor the health of the mammary gland (SANTOS \& FONSECA, 2019). After milking, postdipping was performed.

The individual milk samples from each lactating cow were collected from the production meter every 15 days, and were refrigerated and sent to the Laboratório de Serviços de Rebanhos Leiteiros (SARLE) of the Universidade de Passo Fundo (UPF) the following day, which is certified by the Ministério da Agricultura, Pecuária e Abastecimento (MAPA) of Brazil. Total dry extract (TDE) and defatted extract (DDE), and lactose, fat, protein, casein, and milk urea nitrogen (MUN) contents were determined by near infrared spectroscopy (NIRS, Bentley 2000, Bentley Instruments, USA). Somatic cell count (SCC) was determined by flow cytometry (Somacount 300, Bentley Instruments, USA). Subsequently, other components (Other; minerals and vitamins; (1)) and milk energy (ME; (2)) were calculated according to the equations below:

$$
\begin{aligned}
& \text { Other }=\text { TDE }-(\text { Fat }+ \text { Protein }+ \\
& \quad \text { Lactose }) \\
& M E=((\text { Fat } P * 9.29)+(\text { Prot } P * \\
& 5.47)+(\text { Lac } P * 3.95)) \quad \text { which } \quad \text { Fat } P= \\
& \text { In } \quad \text { Fat production }\left(\frac{\mathrm{kg}}{\mathrm{kg}} \text { of milk }\right) \\
& \text { ProtP }= \\
& \text { Protein production }\left(\frac{\mathrm{kg}}{\mathrm{kg}} \text { of milk }\right), \text { and }
\end{aligned}
$$

$$
\begin{aligned}
& \text { LacP }= \\
& \text { Lactose production }\left(\frac{\mathrm{kg}}{\mathrm{kg}}\right. \text { of milk) }
\end{aligned}
$$

were taken to be $9.29,5.47$, and 3.95 , respectively, and represent the amounts of energy released by the combustion of $1 \mathrm{~kg}$ of fat, protein, and lactose, respectively (Mcal/kg; NRC, 2001).

Milk production was corrected (MPc) to $3.5 \%$ fat according to the following equation (3) by Tyrrell \& Reid, (1965):

$M P c 3.5=(12.82 *$ FatP $)+(7.13 *$

ProtP $)+(0.323 *$ LacP $)$

Body condition score (BCS) was assessed using a scale from 1 to 5 , as described by Edmonson et al., (1989). Cows' udder dirt was assessed using a methodology adapted from those described in Schreiner \& Ruegg (2002) and Ruegg (2003), and the score given was subjective based on the following grades: 1) completely free of $\operatorname{dirt}(0-1$ $\%$ dirt on the udder surface); 2) slightly dirty $(2-10 \%$ dirt on the surface of the udder); 3) mainly covered with dirt (11 $30 \%$ dirt on the surface of the udder); or 4) completely covered, dirty with soil ( $>$ $30 \%$ dirt from the udder surface). These observations were made before predipping. As the birth order and lactation days are important for managing dairy herds, such information was collected on both farms.

As the characteristics of the herds and management practices in the properties were similar, a single database was created containing all the evaluates information. Data were evaluated through descriptive statistical analyzes, namely the UNIVARIATE, MEANS, and FREQ procedures and by multivariate analysis techniques (factor analysis and grouping), using the SAS ${ }^{\circledR}$ statistical software (SAS Institute, 2004). To carry out statistical analyzes, the calving order was considered as follows: primiparous cows (64 
individuals), second lactation cows (46 individuals), and cows with three or more lactations (133 individuals) were considered as multiparous. In both properties the management was carried out to have, on average, 30 lactating cows. Therefore, births occurred throughout the whole year.

The SCC was transformed using the following equation proposed by Ali \& Shoock (1980):

$$
S C S=\log 2(S C C / 100)+3
$$

where: $\quad S C S=$ somatic cell score; $\log 2=$ base 2 logarithm;

Factor analysis was used to assess the relationships between variables, with the aim of reducing the original set of variables to a smaller number of factors, with each factor representing the relationships among the variables that compose it. Factor analysis was performed using the FACTOR procedure in SAS, and Kaiser-MeyerOlkin (KMO) statistics were used in order to verify the adequacy of the model. The variables were selected to compose each of the factors based on their commonality. The rotation used was Promax, which is an oblique rotation that considers the relationships among the factors.

Cluster analysis was performed using the FASTCLUS procedure in SAS in order to form groups of observations with homogeneous characteristics within groups and heterogeneous characteristics between groups. Ward's hierarchical method based on Euclidean distance was used to estimate the standardized means of the groups, and then the original averages for each group were transformed. Subsequently, discriminant analysis was performed using the DISCRIM procedure in SAS in order to classify the observations correctly within each group, and the
STEPDISC procedure was performed using the STEPWISE method in order to select the variables responsible for differentiation among the groups, taking variables presenting $\mathrm{P}>0.0001$ into consideration. Partial $\mathrm{R}^{2}$ values were used to explain how much each variable was responsible for the differentiation of the groups. Since a considerable proportion of observations were distributed incorrectly within their respective groups, the decision to use nonparametric discriminant analysis obtained by the NPAR1WAY method was taken, through the nearest neighbor (KNN) algorithm, which correctly classified all observations within the groups.

Finally, in order to compare the means of the groups formed by the cluster analysis, the assumptions of normality (Shapiro-Wilk test) and homogeneity of variances (Levene test) were tested, with the majority of variables presenting $\mathrm{P}$ $<0.0001$ for both Shapiro-Wilk and Levene tests. Therefore, at least one of the assumptions was not met by all variables, indicating a lack of normality or homogeneity of variances. Given this fact, analysis of variance using the GLIMMIX procedure was employed, which takes the type of distribution of the response variable into consideration when comparing means and uses the LSMEANS procedure. Means were compared by Tukey-Kramer tests, at the $5 \%$ probability level. Normal identity distribution was used for all analyzed variables, in which the identity link function made the connection between the averages of the observations and the systematic part.

\section{RESULTS AND DISCUSSION}


Despite the care taken in the management of both herds, undesirable maximum values (Table 1) were observed for days in lactation (497), maximum udder dirt (4.00), SCC (1,906.00), and SCS (7.25). There were also undesirable minimum values for BCS (1.75), DDE (7.84\%), fat $(2.30 \%)$, protein $(2.56 \%)$, lactose $(3.71 \%)$, and others components (minerals and vitamins; $0.26 \%$ ), demonstrating that individual control needs to be carried out effectively to facilitate quick decisionmaking and bioeconomic responses. However, the values previously mentioned are not representative; that is, the average values for the other evaluated parameters were adequate.

It is noteworthy that the observed average milk production of $26.29 \mathrm{~kg}$ milk day ${ }^{-1}$ is compatible with the semiconfined system, which produces maximum values of up to $55.50 \mathrm{~kg}$ milk day $^{-1}$. According to Eckstein et al. (2016) the education level of producers impacts on the quality of the milk produced. Haygert-Velho et al. (2018) emphasizes that the quality of the milk produced at the Escola Estadual Técnica Celeste Gobbato is the result of the training system in place for Técnicos em Agropecuária, which ranges from classes in basic subjects such as Mathematics, Portuguese, Chemistry, Physics, and Biology to the realization of good farming practices in the Milk Bovine Production Educational Unit (practical classes).

Table 1. Descriptive statistics on the production conditions in two dairy herds in northwestern Rio-grandense mesoregion of Rio Grande do Sul.

\begin{tabular}{|c|c|c|c|c|c|}
\hline \multirow[b]{2}{*}{ Variables } & \multicolumn{5}{|c|}{ Descriptive statistics } \\
\hline & $\mathrm{N}$ & $\underset{\mathrm{m}}{\operatorname{Minimu}}$ & Average & $\underset{\mathrm{m}}{\operatorname{Maximu}}$ & SD \\
\hline \multicolumn{6}{|c|}{ Parameters related to cows } \\
\hline Calving order & 243 & 1.00 & 2.11 & 3.00 & 0.89 \\
\hline Lactation days & 243 & 9.00 & 198.69 & 497.00 & 134.48 \\
\hline Body condition score (BCS) & 216 & 1.75 & 2.73 & 3.75 & 0.34 \\
\hline Udder dirt* & 212 & 1.00 & 1.64 & 4.00 & 0.79 \\
\hline Milk production & 213 & 10.50 & 26.29 & 55.50 & 8.36 \\
\hline Corrected milk production $3.5 \%$ & 213 & 11.80 & 27.26 & 50.22 & 7.88 \\
\hline \multicolumn{6}{|c|}{ Milk composition } \\
\hline Total dry extract $(\%)$ & 243 & 10.53 & 12.81 & 16.56 & 1.13 \\
\hline Defatted dry extract (\%) & 243 & 7.84 & 8.87 & 9.93 & 0.43 \\
\hline Fat $(\%)$ & 243 & 2.30 & 3.95 & 7.08 & 0.84 \\
\hline
\end{tabular}




$\begin{array}{llllll}\text { Protein (\%) } & 243 & 2.56 & 3.31 & 4.48 & 0.39 \\ \text { Casein (\%) } & 243 & 2.10 & 2.63 & 3.50 & 0.29 \\ \text { Lactose (\%) } & 243 & 3.71 & 4.55 & 5.06 & 0.19 \\ \text { Others (\%) } & 243 & 0.26 & 0.99 & 1.28 & 0.06 \\ \text { Milk energy (Mcal/kg of milk) } & 213 & 0.54 & 0.72 & 1.04 & 0.08 \\ \text { Milk urea nitrogen (mg/dL) } & 243 & 2.58 & 12.80 & 25.12 & 4.49 \\ \begin{array}{l}\text { Somatic cells count } \\ \text { (cells/mL*1,000) }\end{array} & 243 & 3.00 & 130.99 & 1,906.00 & 231.04 \\ & & & & & \\ \text { Somatic cells score }\left(\log _{2}\right) & 243 & -2.05 & 2.18 & 7.25 & 1,81\end{array}$

*Adapted from Schreiner \& Ruegg (2002) and Ruegg (2003); BCS scale 1 to 5 according to Edmonson et al. (1989).

The average values of casein, urea nitrogen, and milk energy are in accordance with the values found in the NRC (2001). According to Brasil et al. (2015), the casein contents of milk vary from 2.4 to $2.8 \%$, however, in the present study the amplitude was greater, since the evaluations were undertaken per cow and not per expansion tank, which is usually used to evaluate milk composition in rural properties. When evaluating different sources of nitrogen compounds in the diet of lactating cows, De Aguiar et al. (2015) found that casein represented $71.46 \%$ of the total milk protein content on average, and in the present study the average was $79.46 \%$, demonstrating that the milk from the two rural properties was suitable for industrialization due to the average total dry extract $(12.81 \%)$ and the average SCC. Although average values of milk urea nitrogen $(12.80 \%)$ were verified in the two rural properties, the minimum value of $2.58 \%$ and the maximum value of $25.12 \%$ are noteworthy for their range. This range is probably due to variation in consumption of food, as food consumptions is known to be quite variable dairy cows (NRC, 2001), and to the changes in diet according to the seasons (Milani et al., 2015; Stürmer et al., 2018).

When assessing the health of the mammary glands, udder dirt, body condition score, production, and milk composition in cows from two properties in northwestern Rio Grande do Sul, factor analysis explained $68.9 \%$ of the total variance in the first four factors with a KMO of 67.3 (Table 2). The high communalities for all variables demonstrate the importance of these variables in explaining the relationships shown in the evaluated data set. 
Table 2. Factor loads, eigenvalues, percentage of variance explained by, and commonality of each variable referring to factor analysis

\begin{tabular}{lccccc}
\hline Variables & \multicolumn{2}{c}{ Factors formed by factor analysis } & Communality \\
& 1 & 2 & 3 & 4 & \\
\hline Breed & $\mathbf{0 . 9 2 1}$ & -0.242 & -0.012 & -0.100 & 0.791 \\
Fat (\%) & $\mathbf{0 . 8 0 1}$ & 0.021 & -0.015 & 0.115 & 0.656 \\
Protein (\%) & $\mathbf{0 . 6 4 2}$ & $\mathbf{0 . 4 7 5}$ & -0.030 & 0.086 & 0.812 \\
Milk production (kg milk day & $\mathbf{- 0 . 6 3 0}$ & -0.246 & 0.014 & 0.166 & 0.593 \\
1) & & & & & \\
Lactation days & 0.097 & $\mathbf{0 . 8 7 5}$ & 0.117 & 0.078 & 0.806 \\
Body condition score (BCS) & -0.171 & $\mathbf{0 . 6 6 2}$ & $\mathbf{- 0 . 3 8 6}$ & -0.159 & 0.663 \\
Lactose (\%) & -0.056 & 0.085 & $\mathbf{0 . 8 1 4}$ & -0.092 & 0.649 \\
Somatic cells score (log $)$ & 0.011 & 0.155 & $\mathbf{- 0 . 6 6 6}$ & 0.003 & 0.490 \\
Calving order & 0.001 & -0.062 & $\mathbf{- 0 . 4 3 0}$ & $\mathbf{0 . 7 5 2}$ & 0.680 \\
Udder dirt* & -0.054 & 0.072 & $\mathbf{0 . 3 6 4}$ & $\mathbf{0 . 7 4 9}$ & 0.752 \\
\hline \% of variance explained & 30.0 & 16.4 & 11.8 & 10.7 & \\
\hline Breed & & &
\end{tabular}

Breed: 1 = Holstein and 2 = Jersey; * Adapted according to Schreiner \& Ruegg (2002) and Ruegg (2003); BCS scale 1 to 5 according to Edmonson et al. (1989).

The first factor comprises the negative relationships between milk production and breed, fat, and protein contents, with Jersey cows producing less milk with higher fat and protein contents compared to Holstein cows. Assessing Holstein, Jersey, and crossbred herds with different genetic degrees in a rural property in Santa Catarina, Felippe et al. (2017) found that Jersey cows produced less milk, even when milk production was corrected for $4 \%$ fat. Jersey cows produced milk with higher $(\mathrm{P}<0.05)$ fat content $(4.66 \%)$ than Holstein cows $(3.76 \%)$. The presence of Jersey cows in the herds of rural properties can help farmers to obtain monetary bonuses in relation to the fat content parameter.
Thus, in northwestern Rio Grande do Sul, the use of mixed herds is common, as in the two evaluated rural properties.

The second factor comprised the positive relationship between days in lactation and body condition score and milk protein content, with increased lactation days leading to improved body condition score and increased milk protein content. According to the NRC (2001), the negative energy balance at the beginning of lactation is physiological and occurs in practically all cows, regardless of the level of production, and the beginning of recovery of BCS, at most until 90 days of lactation, is essential to minimize productive (bonus for the composition of milk) and reproductive (adequate birth 
interval) losses. When assessing how different levels of concentrate in the prepartum and postpartum period affected milk production and body score of dairy cows, Salmazo et al. (2012) concluded that increasing the level of supplementation in the prepartum period improves BCS, but not the milk production of animals, and that increasing supplementation in the postpartum period improves both BCS and milk production.

The third factor was represented by the negative relationships between lactose content with SCS, calving order, and $\mathrm{BCS}$, meaning that lactating cows that produce milk with a higher lactose content have lower milk SCC, lower body condition, and are younger. Despite a weaker correlation being found (0.364), this group of younger cows with lower SCC also had dirtier udders. This factor demonstrates two important principles: first, young cows (primiparous) are healthier with respect to mastitis, which in turn does not compromise the synthesis of lactose. Another important finding was that CMT tests in revealed that $76 \%$ of the evaluated mammary rooms did not present mastitis (score 0), while 10, 10, 2 , and $2 \%$ presented traits that warranted mild viscosity scores, score + (mild to moderate), score ++ (moderate), and score +++ (intense viscosity), respectively, following the methodology described in Santos \& Fonseca (2019). According to Haile-Mariam \& Price (2017), SCC is used in several countries as an indicator of mammary gland health and is used to genetically improve the herd. In Brazil, it is recommended that SCC be less than $500,000 \mathrm{~mL}^{-1}$ (Brasil, 2018). High concentrations of SCC in the milk are indicative of inflammation in the mammary glands of lactating cows (Busanello et al., 2017b). However, in the present study, the incidence of mastitis was reduced, demonstrating the adequate sanitary management of the herds. It is also noteworthy that young cows had a lower body condition score, emphasizing the importance that should be placed on the creation and development of calves and heifers, as well as first lactation cows (NRC, 2001). In the fourth factor, there was a positive relationship between birth order and udder dirt, with multiparous cows with a higher number of lactations possessing dirties udders. This may be related to the depth of the udder, since cows with a higher number of lactations due to high milk production present udders below the hock line. However, considering the semi-confinement system (pasture supplemented with roughage and concentrated in the trough), it was observed that $51.6 \%$ of the cows had clean udders (grade 1), 36.6\% were scored grade $2,8.0 \%$ grade 3 , and only $3.8 \%$ of udders were considered dirty, with some collections taking place on rainy days. Cleaning the pre-milking ceiling is of fundamental importance for obtaining milk with low microbiological contamination (Córdova et al., 2018). In milking management, the other fundamental procedures are pre-dipping, which minimizes the presence of microorganisms in raw milk (Silva et al., 2018), and post-dipping, which prevents contamination of the mammary gland (Machado et al., 2017).

STEPDISC analysis was performed within the discriminant analysis, using the STEPWISE method, which selected the variables that made up the final model $(\mathrm{P}<0.0001)$ as well as those that were responsible for the differentiation of the groups (Table 3 ). The protein and lactose content, breed, milk production, and body condition score were considered to be important in the 
differentiation of the groups, based on the fact that they achieved $\mathrm{P}<0.0001$ and partial $\mathrm{R}^{2}$ values, which explain how much each variable is responsible for the differentiation of the groups. Thus, $55.1 \%$ of the differentiation between the groups was explained by milk protein content, and the remaining responsible variables are presented in Table 3 in order of the degree of importance of each variable, according to partial $\mathrm{R}^{2}$ values.

Table 3. Discriminant analysis of the variables responsible for the differentiation of the groups, and their respective statistical parameters

\begin{tabular}{lcccc}
\hline Variables & $\begin{array}{c}\text { Partial } \\
\mathrm{R}^{2}\end{array}$ & $\mathrm{P}>\mathrm{F}$ & $\mathrm{P}<$ Lambda & $\mathrm{P}>$ ASCC \\
\hline Protein (\%) & 0.551 & $<0.0001$ & $<0.0001$ & $<0.0001$ \\
Lactose (\%) & 0.315 & $<0.0001$ & $<0.0001$ & $<0.0001$ \\
Breed & 0.241 & $<0.0001$ & $<0.0001$ & $<0.0001$ \\
Milk production (kg milk day $\left.{ }^{-1}\right)$ & 0.152 & $<0.0001$ & $<0.0001$ & $<0.0001$ \\
Body condition score (BCS) & 0.081 & $=0.0177$ & $<0.0001$ & $<0.0001$ \\
\hline
\end{tabular}

BCS scale 1 to 5 according to Edmonson et al. (1989). ASCC = Average Squared Canonical Correlation.

Cluster analysis revealed three groups (Table 4), which were verified by canonical analysis that graphically demonstrated the Euclidean distances used in the between- and within-group separations (Figure 1). All evaluated variables differed according to the groups formed. Group 1 was characterized by lactating Holstein cows, with higher milk production and lower milk protein and fat contents, together with fewer lactation days, lower BCS, and greater udder dirt compared to group 2. Group 2 consisted of lactating cows of the Holstein breed and a considerable number of Jersey cows, and was characterized by lower milk production and higher milk fat and protein contents, together with a greater number of days in lactation and higher BCS, but with less udder dirt. Calving order, lactose content, and SCS did not differ between groups 1 and 2. Group 3 consisted of Holstein cows and a small percentage of Jersey cows, differing from the first two groups due to the higher calving order, increased SCS, lower milk lactose content, less udder dirt, and intermediate milk protein content. The data showed that under these experimental conditions, even in semi-confinement, udder dirt was not correlated with the incidence of mastitis in herds, since cows with higher SCS had less udder dirt. Another important fact to consider is that only 13 animals made up group 3 (i.e., lactating cows with high SCS). Only group 3 was not in accordance with normative instruction No76 (Brasil, 2018) regarding somatic cell count. According to Demeu et al. (2016), preventive treatments for mastitis during lactation contribute to reducing the economic impact of the disease when cows are affected. The results of the aforementioned study help to explain the low frequency of cows with high SCS, since both rural 
properties performed daily pre-dipping and post-dipping.

Table 4. Groupings formed by variables based on the production conditions of two dairy herds in the northwestern Rio-grandense mesoregion of Rio Grande do Sul.

\begin{tabular}{|c|c|c|c|c|}
\hline \multirow{2}{*}{ Variables } & \multicolumn{3}{|c|}{ Groups formed by cluster analysis } & \multirow{2}{*}{$\mathrm{P}$} \\
\hline & 1 & 2 & 3 & \\
\hline Breed & $1.00 \mathrm{~b}$ & $1.56 \mathrm{a}$ & $1.15 \mathrm{a}$ & $<0.0001$ \\
\hline Calving order & $2.15 \mathrm{~b}$ & $1.98 \mathrm{~b}$ & $2.69 \mathrm{a}$ & $=0.0192$ \\
\hline Body condition score (BCS) & $2.64 \mathrm{c}$ & $2.79 \mathrm{~b}$ & $3.19 \mathrm{a}$ & $<0.0001$ \\
\hline Lactation days & $132.60 \mathrm{~b}$ & $272.30 \mathrm{a}$ & $293.38 \mathrm{a}$ & $<0.0001$ \\
\hline $\begin{array}{l}\text { Milk production (kg milk } \\
\text { day }^{-1} \text { ) }\end{array}$ & $31.13 \mathrm{a}$ & $20.54 \mathrm{~b}$ & $17.50 \mathrm{~b}$ & $<0.0001$ \\
\hline Fat $(\%)$ & $3.55 \mathrm{~b}$ & $4.52 \mathrm{a}$ & $3.55 \mathrm{~b}$ & $<0.0001$ \\
\hline Protein $(\%)$ & $3.04 \mathrm{c}$ & $3.64 \mathrm{a}$ & $3.50 \mathrm{~b}$ & $<0.0001$ \\
\hline Lactose $(\%)$ & $4.58 \mathrm{a}$ & $4.60 \mathrm{a}$ & $4.10 \mathrm{~b}$ & $<0.0001$ \\
\hline Somatic cells score $\left(\log _{2}\right)$ & $1.92 \mathrm{~b}$ & $2.24 \mathrm{~b}$ & $4.39 \mathrm{a}$ & $<0.0001$ \\
\hline Udder dirt* & $1.81 \mathrm{a}$ & $1.51 \mathrm{~b}$ & $1.08 \mathrm{c}$ & $=0.0001$ \\
\hline Number of observations & 130 & 100 & 13 & \\
\hline
\end{tabular}

Breed: 1 = Holstein and 2 = Jersey; *Adapted according to Schreiner \& Ruegg (2002) and Ruegg (2003); BCS scale 1 to 5 according to Edmonson et al. (1989). 


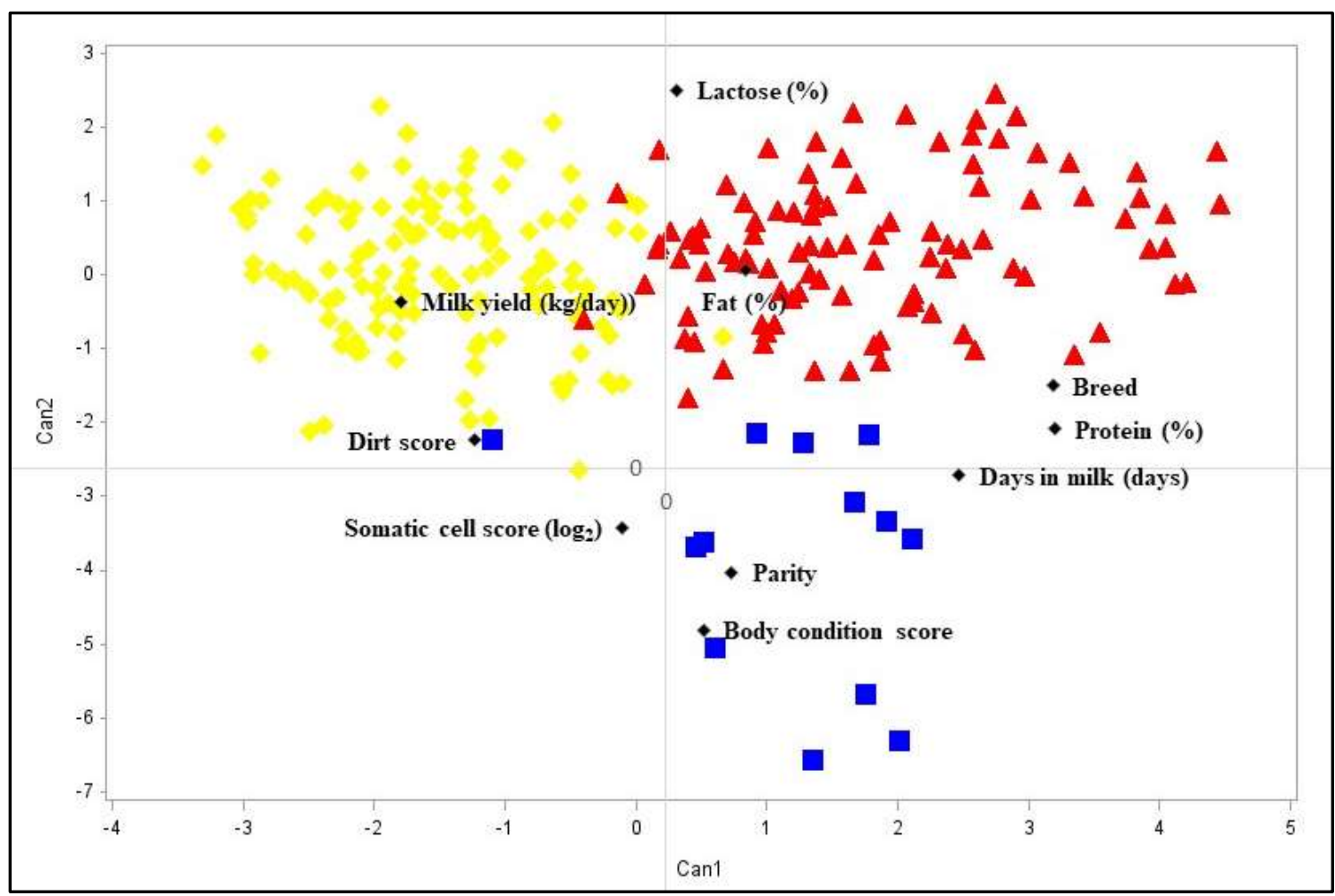

Figure 1. Canonical analysis demonstrated the Euclidean distances between and within the groups formed by the variables that represent group $1(>)$, group $2(\Delta)$, and group 3 ( $\square$ ).

Currently, rural producers and agricultural science professionals prioritize the reduction of production costs. Although evaluating milk composition per cow every 15 days increases expenses, it is a method that should be taken into consideration when making decisions, as it helps farmers to identify drying cows and those that require treatment for subclinical and clinical mastitis. Above all, the method can be used to assess whether the rural producer is achieving the maximum monetary bonuses for milk quality, since a cow with mastitis can compromise the performance of the herd by altering the composition of the milk in the expansion tank.
Paixão et al. (2014) concluded that rural producers who have a structured milking parlor, including an expansion tank, do not always obtain a quick return on invested capital when they implement good agricultural practices, suggesting that their best option of selling would be with a contract establishing the quality and the monetary value of the milk.

\section{CONCLUSIONS}

Monitoring the breed, calving order, body condition score, lactation days, milk production, milk fat, protein, and lactose levels, somatic cells score, and udder dirt of cows allow greater control of the herd, which allows possible 
shortcomings to be rectified quickly and allows productive and economic losses to be minimized.

\section{ACKNOWLEDGMENTS}

This study was financed in part by the Coordenação de Aperfeiçoamento de Pessoal de Nivel Superior - Brasil (CAPES; Finance Code 001). We thank the Fundo de Incentivo à Pesquisa da Universidade Federal de Santa Maria (FIPE - UFSM) for the grant awarded to Júlia Laize Bandeira Calgaro.

\section{REFERENCES}

ALI, A.K.A.; SHOOK, G.E. An optimum transformation for somatic cell concentration in milk. Journal of Dairy Science, 1980. v.63, n.3, p.487-490.

BARBANO, D.M. The production of fluid (market) milk. Journal of Dairy Science, 2017. v.100, n.12, p.98949902.

BAUMAN, D.E.; CURRIE, B. Partitioning of nutrients during pregnancy and lactation: A review of mechanisms involving homeostasis and homeorhesis. Journal of Dairy Science, 1980. v.63, n.9, p.1514-1529.

BAUMGARD, L.H.; COLLIER, R.J.; BAUMAN, D.E. Regulation of nutrient partitioning to support lactation. Journal of Dairy Science, 2017. v.100, n.12, p.10353-10366.

BEWLEY, J.M.; ROBERTSON, L.M.; ECKELKAMP, E.A. Lactating dairy cattle housing management. Journal of
Dairy Science, 2017. v.100, n.12, p.10418-10431.

BRASIL, 2018. Instrução Normativa $n^{\circ}$ 76, de 26 de novembro de 2018. Brasília: Diário Oficial da União 1, 9-10.

BRASIL, R.B.; NICOLAU, E.S.; CABRAL, J.F.; DA SILVA, M.A.P. Estrutura e estabilidade das micelas de caseína do leite bovino. Ciência Animal, 2015. v.25, n.2, p. 71-80.

BUSANELLO, M.; DE FREITAS, L.N.; WINCKLER, J.P.P.; FARIAS, H.P.; DIAS, C.T. dos S.; CASSOLI, L.D.; MACHADO, P.F. Month-wise variation and prediction of bulk tank somatic cell count in Brazilian dairy herds and its impact on payment based on milk quality. Irish Veterinary Journal, 2017a. v.70, n.26, p.1-13.

BUSANELLO, M.; ROSSI, R.S.; CASSOLI, L.D.; PANTOJA, J.C.F.; MACHADO, P.F. Estimation of prevalence and incidence of subclinical mastitis in a large population of Brazilian dairy herds. Journal of Dairy Science, 2017b. v.100, n.8, p.6545-6553.

CAMPOS, R.; LACERDA, L.A.; TERRA, S.R.; GONZÁLEZ, F.H.D. Parâmetros hematológicos e níveis de cortisol plasmático em vacas leiteiras de alta produção no Sul do Brasil. Brazilian Journal of Veterinary Research and Animal Science, 2008. v.45, n.5, p.354361.

CÓRDOVA, H.A.; CARDOZO, L.L.; ALESSIO, D.R.M.; THALER NETO, A. Influência da profundidade do úbere 
na limpeza dos tetos e na saúde da glândula mamária em ordenha robótica. Arquivo Brasileiro de Medicina Veterinária e Zootecnia, 2018. v.70, n.5, p.1443-1452.

DE AGUIAR, A.C.R.; ROCHA JÚNIOR, V.R.; CALDEIRA, L.A.; DE ALMEIDA FILHO, S.H.C.; RUAS, J.R.M.; DE SOUZA, V.M.; DA COSTA, M.D.; PIRES, D.A. de A. Composição do leite de vacas alimentadas com diferentes fontes de compostos nitrogenados. Revista Brasileira de Saúde e Produção Animal, 2015. v.16, n.3, p.591-605.

DEMEU, F.A.; LOPES, M.A.; DA COSTA, G.M.; DA ROCHA, C.M.B.M.; DOS SANTOS, G. Efeito da produtividade diária de leite no impacto econômico da mastite em rebanhos bovinos. Boletim de Indústria Animal, 2016. v.73, n.1, p.53-61.

ECKSTEIN, I.I.; POZZA, M.S.S.; RAMOS, C.E.C.O.; ZAMBOM, M.A.; SANTOS, G.T.; KAZAMA, R.; POZZA, P.C. Typification of factors related to milk production and its impact on the sanitary quality of milk. Scientia Agraria Paranaensis, 2016. v.15, n.1, p.56-63.

EDMONSON, A.J.; LEAN, I.J.; WEAVER, L.D.; FARVER, T.; WEBSTER, G. A body condition scoring chart for Holstein dairy cows. Journal of Dairy Science, 1989. v.72, n.1, p.68-78.

FELIPPE, E.W.; GOMES, I.P. de O.; THALER NETO, A. Comparação de vacas mestiças Holandês x Jersey com vacas puras quanto à eficiência produtiva e reprodutiva. Archives of Veterinary Science, 2017. v.22, n.2, p.48-54.

GONÇALVES， J.L.; CUE， R.I.; BOTARO, B.G.; HORST, J.A.; VALLOTO, A.A.; SANTOS, M.V. Milk losses associated with somatic cell counts by parity and stage of lactation. Journal of Dairy Science, 2018. v.101, n.5, p.4357-4366.

HAILE-MARIAM， M.; PRYCE， J.E. Genetic parameters for lactose and its correlation with other milk production traits and fitness traits in pasture-based production systems. Journal of Dairy Science, 2017. v.100, n.5, p.3754-3766.

HAYGERT-VELHO, I.M.P.; DA CONCEIÇÃO, G.M.; COSMAM, L.C.; ALESSIO, D.R.M.; BUSANELLO, M.; SIPPERT, M.R.; DAMIANI, C.; ALMEIDA, A.P.A.; VELHO, J.P. Multivariate analysis relating milk production, milk composition, and seasons of the year. Anais da Academia Brasileira de Ciências, 2018. v.90, n.4, p.3839-3852.

MACHADO, S.C.; FISCHER, V.; STUMPF, M.T.; STIVANIN, S.C.B. Seasonal variation, method of determination of bovine milk stability, and its relation with physical, chemical, and sanitary characteristics of raw milk. Revista Brasileira de Zootecnia, 2017. v.46, n.4, p.340-347.

MILANI, M.; HENSE, A.; RAHMANI, E.; PLOEGER, A. A pilot investigation of the relationship between climate 
variability and milk compounds under the bootstrap technique. Foods, 2015. v.4, p.420-439.

NATIONAL RESEARCH COUNCIL NRC. Nutrient requirements of dairy cattle. $7^{\text {th }}$ ed. Washington: Academy Press, 2001. 406 p.

PAIXÃO, M.G.; LOPES, M.A.; PINTO, S.M.; DE ABREU, L.R. Impacto econômico da implantação das boas práticas agropecuárias relacionadas com a qualidade do leite. Revista Ceres, 2014. v.61, n.5, p.612-621.

ROCHE, J.R.; BERRY, D.P.; BRYANT, A.M.; BURKE, C.R.; BUTLER, S.T.; DILON, P.G.; DONAGHY, D.J.; HORAN, B.; MACDONALD, K.A.; MACMILLAN, K.L. A century of change in temperate grazing dairy systems. Journal of Dairy Science, 2017. v.100, n.12, p.10189-10233.

RUEGG, P.L. Mastitis detection, management, and prevention. Journal of Dairy Science, 2017. v.100, n.12, p.10381-10397.

RUEGG, P.L. Practical food safety interventions for dairy production. Journal of Dairy Science, 2003. v.86, E1-E9.

SALMAZO, R.; MIZUBUTI, I.Y.; RIBEIRO, E.L. de A.; PEREIRA, E.S.; MOREIRA, F.B.; DA ROCHA, M.A.; SENEDA, M.M.; HIROKI, P.T.; KRAWULSKI, C.C. Efeito de diferentes níveis de concentrado no período pré e pósparto sobre a produção de leite e escore corporal de vacas leiteiras. Semina Ciências Agrárias, 2012. v.33, n.3, p.1219-1228.

SANTOS, M.V.; FONSECA, L.F.L. Controle de mastite e qualidade do leiteDesafios e soluções. Ed. dos Autores, 2019.301p.

SCHREINER, D.A.; RUEGG, P.L. Effects of tail docking on milk quality and cow cleanliness. Journal of Dairy Science, 2002. v.85, n.10, p.2503-2511.

SILVA， C.G.; ALESSIO, D.R.M.; KNOB, D.A.; D'OVIDIO, L.; THALER NETO, A. Influência da sanificação da água e das práticas de ordenha na qualidade do leite. Arquivo Brasileiro de Medicina Veterinária e Zootecnia, 2018. v.70, n.2, p.615-622.

Statistical Analysis System [SAS]. (2004). SAS/STAT User guide, version 9.1.2. Cary, NC: SAS Institute Inc.

STÜRMER, M.; BUSANELLO, M.; VELHO, J.P.; HECK, V.I.; HAYGERTVELHO, I.M.P. Relationship between climatic variables and the variation in bulk tank milk composition using canonical correlation analysis. International Journal of Biometeorology, 2018. v.62, n.9, p.1663-1674.

TYRRELL, H.F.; REID, J.T. Prediction of the energy value of cow's milk. Journal of Dairy Science, 1965. v.48, n.9, p.1215-1223.

VON KEYSERLINGK, M.A.G.; WEARY, D.M. Animal welfare in the 
Journal of Dairy Science - The first 100 years. Journal of Dairy Science, 2017. v.100, n.12, p.10432-10444.

WHEELOCK, J.B.; RHOADS, R.P.; VANBAALE, M.J.; SANDERS, S.R.; BAUMGARD, L.H. Effects of heat stress on energetic metabolism in lactating Holstein cows. Journal of Dairy Science, 2010. v.93, n.2, p.644655. 